\title{
Penerapan Model Predict Observe Explain (POE) dalam Peningkatan Berpikir Kritis pada Pembelajaran IPA Tema 6 Cita-Citaku di Kelas IV SD Negeri 1 Kutosari Tahun Ajaran 2018/2019
}

\author{
Marchelina Dwi Saputri ${ }^{1}$, Kartika Chrysti Suryandari ${ }^{2}$, Ngatman ${ }^{3}$
}

1,2,3 Universitas Sebelas Maret

marchelinadwi08@gmail.com

\section{Article History}

accepted 01/10/2019

\begin{abstract}
This study aimed to analyze application of the Predict Observe Explain model, to improve critical thinking on natural science learning of theme 6 my goals. This research is a classroom action research (CAR) collaborative which was carried out for three cycles. The subjects of this study were fourth B grade students of SD N 1 Kutosari in Academic Year 2018/2019, totalling 32 students. Data collection techniques used were observation, interviews, and tests. Data validity used technique triangulation and sources. Data analysis was carried out through data reduction, data presentation, and conclusion drawing. The results of the study indicated that the application of the Predict Observe Explain model could improve critical thinking in grade IV students of SD N 1 Kutosari in Academic Year 2018/2019.
\end{abstract}

Keywords: Predict Observe Explain, Critical thinking

\section{Abstrak}

Tujuan penelitian ini yaitu menganalisis penerapan model Predict Observe Explain, meningkatkan berpikir kritis pada pembelajaran IPA tema 6 cita-citaku. Penelitian ini adalah penelitian tindakan kelas (PTK) kolaboratif yang dilakukan dalam tiga siklus. Subjek penelitian ini adalah siswa kelas IV B SD Negeri 1 Kutosari tahun ajaran 2018/2019 yang berjumlah 32 siswa. Teknik pengumpulan data menggunakan observasi, wawancara dan tes. Validitas data menggunakan teknik triangulasi dan sumber. Analisis data meliputi reduksi data, penyajian data, dan penarikan kesimpulan. Hasil penelitian ini menunjukkan bahwa penerapan model Predict Observe Explain dapat meningkatkan berpikir kritis pada siswa kelas IV SD Negeri 1 Kutosari tahun ajaran 2018/2019.

Kata kunci: predict observe explain, berpikir kritis 


\section{PENDAHULUAN}

Pendidikan merupakan suatu hal terpenting dalam pembangunan nega-ra. Oleh karena itu pendidikan harus sesuai dengan tujuan nasional. Peme-rintah setiap tahunnya melakukan per-baikan untuk pendidikan masa men-datang. Pada Abad 21 tuntutan dunia masa depan dalam bidang pendidikan mengharapkan siswa memiliki keca-kapan berpikir dan belajar. Menurut Hosnan (2014:87) kecakapan yang harus dimiliki siswa pada masa men-datang di antaranya adalah kecakapan pemecahan masalah (Problem solving skill), kecakapan berpikir kritis (Criti-cal Thinking Skill), kolaborasi (colla-boration skill), kecakapan berkomuni-kasi (communication skill) dan kecaka-pan kreativitas (creativity and innova-tion skil). Kompetensi ini sering di-kenal dengan kompetensi 4C.

Kompetensi tersebut dibutuhkan untuk mempengaruhi keberhasilan pendidikan di Indonesia. Penerapan kompetensi 4C dalam dunia pendidik-an memerlukan strategi. Dengan demikian pemerintah menyiapkan sta-tegi untuk menerapkan kompetensi 4C guna menyongsong abad 21. Salah satu stategi yang diambil oleh peme-rintah adalah dengan menerapkan kurikulum yang dapat mencakup kom-petensi $4 \mathrm{C}$ tersebut.

Sejak tahun 2013 pemerintah mengeluarkan kebijakan tentang pene-rapan kurikulum baru yang kemudian dikenal dengan kurikulum 2013. (Akbar dkk,2016:2) Penerapan kuriku-lum 2013 dilakukan secara bertahap. Pada saat ini sebagian besar sekolah sudah menerapkan kurikulum 2013. Pembelajaran di dalam kurikulum 2013 menurut Kemendikbud (2014:16) memiliki karakteristik: (1) berpusat pada siswa, (2) menuntut siswa aktif dalam pembelajaran, (3) memberikan pengalaman langsung pada siswa, (4) bersifat luwes, (5) hasil pembelajaran dapat berkembang sesuai dengan minat dan kebutuhan siswa, (6) mengem-bangkan keterampilan berpikir kritis siswa, serta (7) menggunakan pen-dekatan ilmiah.

Berdasarkan wawancara dan ob-servasi di kelas IV B SDN 1 Kutosari pada tanggal 12 November

2018. Pe-neliti menemukan beberapa masalah dalam pembelajaran IPA antara lain: (1) pembelajaran IPA dilaksanakan masih secara konvensional, mengguna-kan metode ceramah dan tanya jawab. (2) pemahaman siswa terhadap konsep masih rendah. (3) siswa masih belum paham dengan pembelajaran yang di-sedang dipelajari. (4) terbatasnya ma-teri pada buku pegangan siswa (5) ke-terampilan berpikir kritis belum ber-kembang secara optimal. Belum opti-malnya keterampilan berpikir kritis siswa mengakibatkan hasil belajar muatan IPA di kelas IV B SDN 1 Kutosari dapat dibilang masih rendah.

Rendahnya hasil belajar muatan IPA diperkuat dengan data Penilaian Tengah Semester 1 tema II Selalu Berhemat Energi. Hasil menunjukkan siswa yang lulus KKM hanya sebesar $43,75 \%$ sedangkan siswa yang tidak lulus $\mathrm{KKM}$ sebesar $56,25 \%$ atau 18 siswa dari 32 siswa.

Berdasarkan permasalahan di atas, peneliti berupaya memberikan solusi untuk menerapkan model pem-belajaran Predict Observe Explain (POE). Hal ini karena model Predict Obsere Explain (POE) siswa dibelajar-kan untuk menemukan pengetahuan berdasarkan apa yang mereka amati. Hal ini sejalan dengan langkah berpikir kritis menjadikan seseorang berusaha untuk mengumpulkan data sampai menyimpulkan hasil observasi dengan masuk akal.

Amal dkk (2013:85) menyata-kan bahwa model pembelajaran Predict Observe Explain (POE) meru-pakan model pembelajaran yang mem-belajarkan siswa dengan membuat prediksi atas suatu konsepsi mereka sendiri, kemudian mengobservasi kejadian tersebut secara nyata, dan yang terakhir menjelaskan ketidaksesuaian prediksi yang telah dibuat mereka dengan keadaan yang sebenarnya.

Berdasarkan uraian di atas, dapat dirumuskan masalah sebagai berikut: (1) bagaimana penerapan model Predict Observe Explain pada pembelajaran IPA tema 6 
cita-citaku; (2) apakah penerapan model Predict Observe Explain dapat meningkatkan berpikir kritis.

Tujuan penelitian ini yaitu (1) menganalisis penerapan model Predict Observe Explain, (2) meningkatkan berpikir kritis pada pembelajaran IPA tema 6 cita-citaku melalui penerapan model Predict Observe Explain.

\section{METODE}

Penelitian ini dilaksanakan di SD Negeri 1 Kutosari. Subjek penelitian ini adalah siswa kelas IV B yang berjumlah 32 siswa yang terdiri dari 22 siswa laki-laki dan 10 siswa perem-puan.

Data pada penelitian ini ada dua macam yaitu data mengenai penerapan model Predict Observe Explain dan data mengenai hasil berpikir kritis. Adapun teknik pengumpulan data yang digunakan adalah observasi, wawan-cara dan tes. Pendekatan yang diguna-kan dalam penelitian ini adalah Penelitian tindakan kelas (PTK)

Teknik uji validitas data pada pe-nelitian ini menggunakan teknik tri-angulasi yaitu triangulasi teknik dan triangulasi sumber. Triangulasi teknik yang digunakan yaitu observasi, wa-wancara dan tes. Adapun triangulasi sumber yang digunakan yaitu siswa dan guru. Teknik analisis data yang digunakan dalam penelitian ini yaitu reduksi data, penyajian data, dan pena-rikan kesimpulan sesuai model analisis data menurut Miles dan Huberman (Sugiyono, 2015:338)

Indikator kinerja penelitian ini adalah penerapan model Predict Ob-serve Explain dan peningkatan ber-pikir kritis siswa ditargetkan menca-kup $85 \%$. Adapun prosedur penelitian ini menggunakan model penelitian tin-dakan kelas yang terdiri dari empat tahapan, yaitu (1) perencanaan, (2) pe-laksanaan, (3) observasi, (4) refleksi.

\section{HASIL DAN PEMBAHASAN}

Penerapan model Predict Obser-ve Explain dalam peningkatan berpikir kritis pada pembelajaranIPA tema 6 cita-citaku di kelas IV SD Negeri 1 Kutosari dilakukan dalam tiga siklus. Setiap siklus terdiri dari dua pertemuan.

Proses pembelajaran dilaksana-kan dengan langkah-langkah sebagai berikut:(1) pemberian orientasi dan motivasi, (2) pengenalan eksperimen, (3) penentuan prediksi, (4) pelak-sanaan observasi, (5) penjelasan, (6) follow up. Langkah-langkah model Predict Observe Explain tersebut mengacu pada langkahlangkah yang dikemukakan oleh Wardani (2015:36) yang kemudian disimpulkan menjadi langkah-langkah yang sudah disebut-kan di atas.

Analisis penerapan model Predict Observe Explain dalam pembelajaran dilaksanakan tiga siklus mengalami beberapa kendala yaitu: (1) siswa me-milih teman kelompoknya, (2) siswa menulis hasil prediksi dan hasil panga-matan membutuhkan waktu lama, (3) siswa kurang fokus pada saat pembelajaran, (4) kelas kurang kondusif saat melaksanakan kegiatan tanya jawab. Hal ini sejalan dengan pendapat Indrawati, Wawan (2009:45) kendala model Predict observe explain yaitu (1) memerlukan waktu yang lebih matang, (2) memerlukan alat dan bahan dan tempat yang memadai, (3) memerlukan kemampuan dan keteram-pilan khusus dari guru.

Solusi dari kendala-kendala di atas yaitu (1) guru memberikan pe-ngertian bahwa semua teman sama, (2) guru memberikan waktu tambahan waktu untuk menulis hasil prediksi dan hasil observasi serta memberikan motivasi siswa agar menyelesaikan pekerjaannya. Hal ini sejalan dengan pendapat Indriani (2016:136) motivasi adalah dorongan yang menyebabkan yang menyebabkan terjadinya suatu perbuatan guna mencapai suatu tujuan. (3) guru memberikan ice breaking saat siswa mulai kurang fokus pada pem-belajaran. Hal ini sesuai dengan pene-litian Irachmat (2015:9) yang menya-takan perhatian siswa meningkatkan perhatian siswa saat siswa tidak fokus, (4) 
guru memberikan peraturan yang hendak menjawab/bertanya dipersilah-kan mengangkat tangannya terlebih dahulu.

Hasil observasi penerapan model Predict Observe Explain mengamati peningkatan setiap siklusnya hingga mencapai kinerja penelitian yaitu $85 \%$.

Tabel 1. Persentase Hasil Observasi Guru dan Siswa

\begin{tabular}{llll}
\hline & $\begin{array}{l}\text { Siklus } \\
\text { I }(\%)\end{array}$ & $\begin{array}{l}\text { Siklus } \\
\text { II }(\%)\end{array}$ & $\begin{array}{l}\text { Siklus } \\
\text { III }(\%)\end{array}$ \\
\hline Guru & 73,84 & 88,89 & 93,63 \\
Siswa & 72,92 & 88,42 & 92,47 \\
\hline
\end{tabular}

Berdasarkan tabel 1, persentase rata-rata hasil observasi guru pada sik-lus I yaitu $73,84 \%$, siklus II meningkat menjadi $88,89 \%$, dan siklus III men-jadi 93,63\%. Hasil observasi siswa pada siklus I yaitu $72,92 \%$, meningkat pada siklus II yaitu $88,42 \%$, dan siklus III yaitu $92,47 \%$.

Tabel 2. Hasil tes berpikir kritis

\begin{tabular}{llll}
\hline \multicolumn{4}{c}{ Persentase (\%) } \\
& Siklus I & Siklus II & Siklus III \\
\hline Tuntas & 68,75 & 84,375 & 87,5 \\
Belum & 31,25 & 15,625 & 12,5 \\
Tuntas & & & \\
\hline
\end{tabular}

Berdasarkan tabel 2, dapat di-simpulkan bahwa terjadi peningkatan hasil tes berpikir kritis dari siklus I yaitu $68,75 \%$, siklus II menjadi $84,375 \%$ dan siklus III yaitu $87,5 \%$.

Keterampilan berpikir kritis juga dapat diukur menggunakan teknik ob-servasi selama pembelajaran. Hasil ob-servasi dijadikan data pendukung hasil tes berpikir kritis. Hasil observasi kete-rampilan berpikir kritis pada siklus I, II, dan III dapat dilihat di tabel 3.

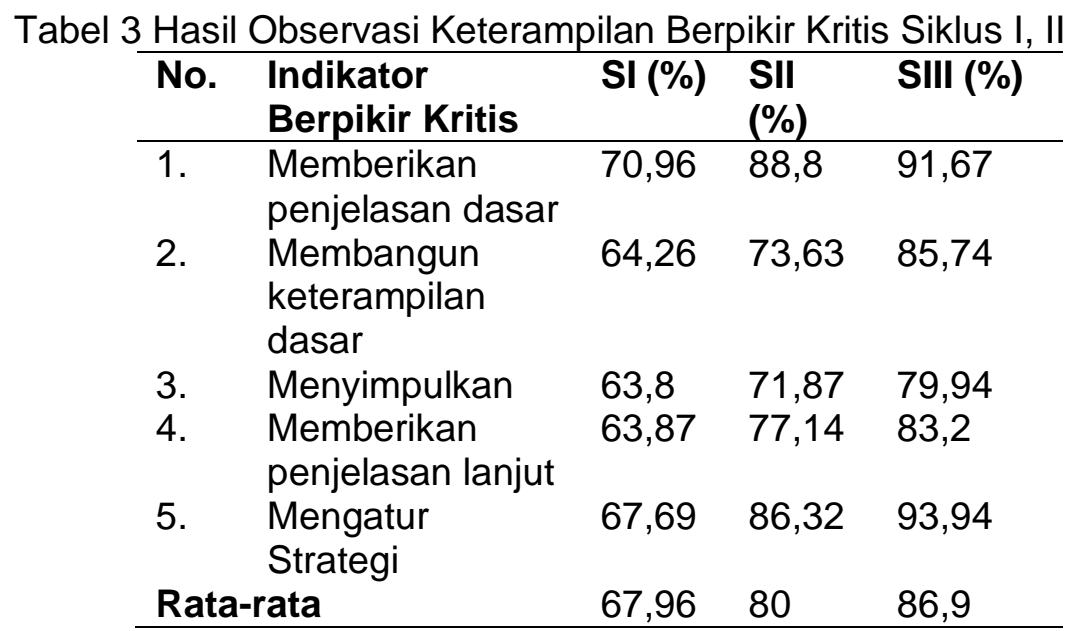

Berdasarkan tabel 3, dapat di-ketahui bahwa keterampilan berpikir kritis meningkat dari siklus I sampai siklus III antara $67,96 \%-86,9 \%$.

Dengan demikian penerapan mo-del Predict Observe Explain (POE) dapat meningkatkan berpikir kritis siswa yang dapat dilihat dari persenta-se siswa yang memenuhi ketercapaian target dari siklus I, II dan III. Hasil ini diperkuat dengan 
penelitian yang dila-kukan Ulfah, Asim dan Parno (2014:1) menyatakan bahwa model Predict Ob-serve Explain (POE) dapat mening-katkan keterampilan berpikir kritis dan motivasi belajar siswa.

\section{SIMPULAN}

Penerapan model Predict Ob-serve Explain (POE) untuk meningkat-kan berpikir kritis pada pembelajaran IPA tema 6 cita-citaku di kelas IV SD Negeri 1 Kutosari tahun ajaran 2018/2019 dilaksanakan dengan langkah-langkah: (1) pemberian orien-tasi dan motivasi, (2) pengenalan eksperimen, (3) penentuan predik-si, (4) pelaksanaan observasi, (5) pen-jelasan, (6) follow up.

Penerapan model Predict Ob-serve Explain (POE) memiliki ken-dala yaitu (1) siswa menulis hasil prediksi dan hasil pangamatan membutuhkan waktu lama, (2) siswa kurang fokus pada saat pembelajaran. Solusi dari kendala yang ditemui yaitu (1) guru memberikan waktu tambahan, memberikan batasan waktu dan moti-vasi agar siswa menulis hasil prediksi dan hasil observasi dengan tepat wak-tu, (2) guru memberikan ice breaking saat siswa mulai kurang fokus pada pembelajar-an.

Penerapan model Predict Ob-serve Explain (POE) untuk mening-katkan pada pembelajaran IPA tema 6 cita-citaku di kelas IV SD Negeri 1 Kutosari tahun ajaran 2018/2019 di-tunjukkan dengan peningkatan per-sentase siswa pada setiap siklus yang memenuhi target indikator penelitian sebesar $85 \%$.

\section{DAFTAR PUSTAKA}

Akbar dkk. (2016). Implementasi Pembelajaran Tematik di Sekolah Dasar. Bandung:

Remaja Rosdakarya

Amal dkk. (2013). Pengembangan Model Pembelajaran Predict,Observe, Discuss,dan Explain (PODE) untuk meningkatkan hasil belajar IPA Sekolah Dasar Negeri Kompleks IKIP Makassar. Journal of Primary Educational. 2 (2) 84-90

Hosman. (2014). Pendekatan Saintifik dan Kontekstual dalam Pembelajaran Abad 21. Bogor: Ghalia Indonesia.

Sugiyono. (2015). Metode Penelitian Kuantitaif Kualitatif dan R\&D. Bandung: Alfabeta.

Ulfah, Asim dan Parno. (2014). Penerapan Model Pembelajaran POE (Predict Observe Explain) untuk Meningkatkan Kemampuan Berpikir Kritis Dan Motivasi Belajar Siswa Kelas X-MIA 4 SMA N 6 Malang dalam Materi Fisika Kalor. Journal Universitas Malang 1(1)1-12

Wardani, L. (2015). Penerapan Model Kolaboratif Teknik Predict Observe Explain (POE) dengan Media Konkret dalam Peningkatan Pembelajaran IPA di Kelas V SDN 2 Kemangguan Tahun Ajaran 2014/2015. Skipsi. Universitas Sebelas Maret Surakarta. 